\title{
Breastfeeding self-efficacy: a cohort study
}

\author{
Autoeficácia na amamentação: um estudo de coorte
}

Erdnaxela Fernandes do Carmo Souza ${ }^{1}$

Rosa Áurea Quintella Fernandes ${ }^{2}$

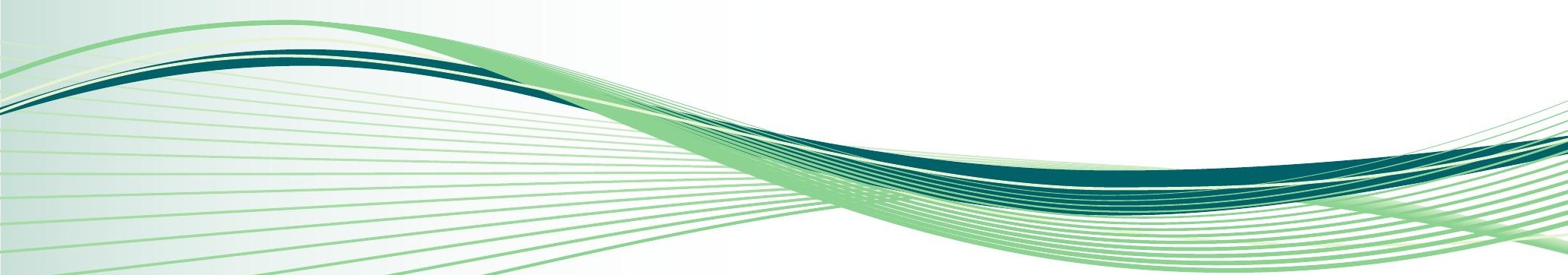

Keywords

Maternal-child nursing; Obstetrical nursing; Breastfeeding; Infant nutrition;

Self-efficacy

Descritores

Enfermagem materno-infantil;

Enfermagem obstétrica; Aleitamento materno; Nutrição do lactente;

Autoeficácia

Submitted

April 29, 2014

Accepted

July 29, 2014

Corresponding author

Rosa Áurea Quintella Fernandes

Teresa Cristina square, 229, Guarulhos,

SP, Brazil. Zip Code: 07023-070

fernands@uol.com.br

DOI

http://dx.doi.org/10.1590/1982-

0194201400076

\section{Abstract}

Objective: Evaluate the clinical use of the Breastfeeding Self-Efficacy Scale as predictive of early weaning and verify if women who had higher self-efficacy scores breastfed for longer periods.

Methods: Cohort study developed with 100 postpartum mothers. Research instrument used: Breastfeeding Self-Efficacy Scale-Short Form. The feeding was monitored on the 7th, 15th, 30th, 45th and 60th day, by phone.

Results: The mean duration of exclusive breastfeeding was 53.2 days (SD 14.2). Most mothers (82.3\%) had scores compatible with high self-efficacy for breastfeeding, none had low efficacy. There was no statistically significant difference in the comparison of mean duration of exclusive and non-exclusive breastfeeding, with the scores of medium and high efficacy.

Conclusion: Findings did not enable the confirmation of the use of the scale as a predictor of risk of early weaning. No relation was observed between higher scores of high efficacy and longer periods of exclusive breastfeeding.

\section{Resumo}

Objetivo: Avaliar o uso clínico da Escala de Autoeficácia na amamentação como preditiva do desmame precoce e verificar se as mulheres que obtiveram maiores escores de autoeficácia amamentaram por mais tempo.

Métodos: Estudo de coorte com 100 puérperas. Instrumento de pesquisa utilizado: Breastfeeding Self-Eficacy Scale-Short Form. 0 aleitamento foi monitorado no $7^{\circ}, 15^{\circ}, 30^{\circ}, 45^{\circ}$ e $60^{\circ}$ dia, por telefone.

Resultados: A média de aleitamento materno exclusivo foi de 53,2 dias (DP 14,2). A maioria das mães $(82,3 \%)$ obteve escores compatíveis com alta autoeficácia para a amamentação, nenhuma apresentou baixa eficácia. Não houve diferença estatisticamente significativa na comparação da média de tempo de aleitamento exclusivo e não exclusivo, com os escores de média e alta eficácia.

Conclusão: Os resultados não permitiram confirmar a utilização da escala como preditiva de risco de desmame precoce. Não se observou relação entre maiores escores de alta eficácia e maior tempo de aleitamento materno exclusivo.
${ }^{1}$ Hospital Samaritano, São Paulo, SP, Brazil.

${ }^{2}$ Universidade Guarulhos, Guarulhos, SP, Brazil.

Conflicts of Interest: there are no conflicts of interest to declare. 


\section{Introduction}

The World Health Organization (WHO) and the United Nations Children's Fund (UNICEF) have undertaken efforts to protect, promote and support exclusive breastfeeding (EBF), so that mothers are able to establish and keep it for the first six months of life of the baby. ${ }^{(1)}$ But this reality in Brazil is still far from being achieved, since the prevalence of exclusive breastfeeding in the first 6 months is only $41 \%$, according to the latest survey conducted in the Brazilian capitals and the Federal District (DF). ${ }^{(2)}$

Breastfeeding $(\mathrm{BF})$ is considered, worldwide, one of the fundamental pillars for promoting and protecting the health of children and its social impact can be quantified through the reduction of medical consultations, hospitalizations and medical treatments, since the child in EBF has lower risk of becoming ill. ${ }^{(3)}$ The obstacles to breastfeeding are numerous, but generally the allegations to its abandonment involve myths and misinformation, even among women with higher socioeconomic status, which confirms the importance of guidance and interventions from healthcare professionals in supporting nursing mothers.

The advancement of public health policies in encouraging BF is increasingly evident. ${ }^{(4)}$ The outlining of these actions is notorious and covers a great part of the women using the public health network. On the other hand, women who do not use this network and are assisted in private institutions not always can count on professional support to help them during the difficulties in BF, especially after discharge.

In this context, it becomes necessary to reformulate strategies, mainly from the private health network, to promote, protect and support EBF, reinforcing the adherence of women who are able to be assisted in the private health network. These mothers generally receive breastfeeding support while hospitalized, however, almost no institution has resources available to maintain this support after delivery in the domicile, or has breastfeeding outpatient services. These deficiencies may favor early weaning in this segment.
Therefore, the institutions and professionals in the private health network are faced with the challenge of implementing breastfeeding care practices during the prenatal, delivery and postpartum periods, mainly because of the need for professional support mothers have in the first days after birth, a phase that is a defining moment to overcome a series of obstacles to breastfeeding and to avoid its abandonment.

Following up mother and baby at a breastfeeding outpatient service, until the tenth day after discharge, represents a strategy that can contribute to reverse an inadequate indication of formula supplementation, or even a possible breastfeeding interruption. ${ }^{(5)}$ Unfortunately, there are only a few private health services that promote monitoring of both mother and child after discharge.

Learning the willingness of mothers to breastfeeding can be a way to predict whether they will maintain the recommended breastfeeding period, which would help professionals to identify difficulties and weaknesses and establish supportive interventions. The application of a breastfeeding self-efficacy scale could point out the mothers with more weaknesses, in the aspects required in the process of breastfeeding, and allow interventions during provision of nursing care that occurs after childbirth, intending to provide support for successful breastfeeding.

A study associated longer periods of EBF with the determination of the mothers to breastfeed, and it recommended attention from health professionals to the absence of mothers' determination to breastfeeding, so that interventions can be performed to consolidate this practice. ${ }^{(6)}$

The objective of this study was to evaluate the clinical use of the Breastfeeding Self-Efficacy Scale as predictive of early weaning and to verify if the women who had higher self-efficacy scores breastfed longer than those who had lower scores.

\section{Methods}

This is a cohort study conducted in a large private hospital, located in an upscale neighborhood of the 
city of São Paulo. The sample was defined by convenience and comprised 100 postpartum women who gave birth in the period between November 2010 and April 2011, and who met the following inclusion criteria: being in postpartum (48-72 hours after delivery); having agreed to participate in the study for up to 60 days after the baby's birth; having a landline or mobile phone number; being breastfeeding exclusively during hospitalization.

The survey instrument used was the Escala de Autoeficácia na Amamentação, the Brazilian version of the Breastfeeding Self-Eficacy Scale-Short Form (BSES-SF). This scale has been validated in Brazil by Dodt in 2008, who applied it in a public hospital in Ceará. ${ }^{(7)}$ This instrumentis clinically useful for nurses to apply in the postpartum period, mainly due to short hospital stays. The scale helps to recognize mothers who are likely to succeed in breastfeeding, providing them with positive reinforcement, as well as those who may need interventions before discharge, in order to provide appropriate and effective assistance. ${ }^{(8)}$

The scale consists of three dimensions (magnitude, generalization and strength) and is based on four sources of information (personal experience, observational or vicarious experience, verbal persuasion and emotional and physiological state). (9) In each rated item, the woman gave a score ranging from 1 to 5 points ( 1 - Strongly disagree 2 Disagree, 3 - Sometimes agree, 4 - Agree and 5 Strongly agree).

For data collection, the women were interviewed once during hospitalization and after childbirth they were contacted by telephone on the $7^{\text {th }}$, the $15^{\text {th }}$, the $30^{\text {th }}$, the $45^{\text {th }}$ and the $60^{\text {th }}$ day to monitor breastfeeding continuity.

For statistical analysis, the data were compiled and analyzed using the SPSS (Statistical Package for Social Sciences), version 16.0. The Kolmogorov-Smirnov test was used to evaluate the adhesion of the dependent and independent continuous variables to the normal distribution curve. The Pearson's correlation coefficient was calculated, and ANOVA was employed to compare the duration of breastfeeding among women with different degrees of self-efficacy in breastfeeding. The chi-square test was used for the association between problems in each stage of BF monitoring. In all analyzes, the level of significance used was $\mathrm{p} \geq 0.05$.

The study development complied with all national and international ethical guidelines for research involving human subjects.

\section{Results}

The sociodemographic profile of the mothers who participated in the study can be outlined as follows: mean age of 32.8 years, ranging from 17 to 44 years; most of them (94.6\%) are married, Catholics (53.1\%), have paid working activities (90\%) and completed higher education (70\%). A total of $47 \%$ were primipara, $43 \%$ secundipara, $87 \%$ of the deliveries were caesarean and $95.3 \%$ reported not having received any guidance on breastfeeding during prenatal care.

The mean time of EBF was 53.2 days (SD 14.2), ranging from 15 to 60 days (Table 1 ).

Tabela 1. Table 1. Frequency of feeding during the postpartum periods analyzed

\begin{tabular}{|c|c|c|c|c|c|}
\hline \multirow{3}{*}{ Type of feeding } & \multicolumn{3}{|c|}{ Days after birth } & \multirow{3}{*}{$\begin{array}{c}45^{\text {th }} \text { Day } \\
n(\%)\end{array}$} & \multirow{3}{*}{$\begin{array}{c}60^{\text {th }} \text { Day } \\
n(\%)\end{array}$} \\
\hline & $7^{\text {th }}$ Day & $15^{\text {th }}$ Day & $30^{\text {th Day }}$ & & \\
\hline & $n(\%)$ & $n(\%)$ & $n(\%)$ & & \\
\hline Exclusive & $100(100.00)$ & $92(92.00)$ & $84(84.00)$ & 81(81.00) & 79(79.00) \\
\hline Supplemented & - & $8(8.00)$ & $15(15.00)$ & $14(14.00)$ & $15(15.00)$ \\
\hline Formula & - & - & $1(1.00)$ & $5(5.00)$ & $6(6.00)$ \\
\hline
\end{tabular}

At the start of monitoring, in the seventh postpartum day, $100 \%$ of the women practiced EBF. However, by the $15^{\text {th }}$ day, $8 \%$ of mothers had introduced a complement, therefore practicing mixed feeding. On the $30^{\text {th }}$ day, $15 \%$ of mothers supplemented breastfeeding with formula and $1 \%$ had weaned the baby. Exclusive breastfeeding showed a progressive decline reaching $79 \%$ at 60 days (Table 2). 
Table 2. Scores obtained by mothers in the application of breastfeeding self-efficacy scale

\begin{tabular}{|c|c|c|}
\hline Score of self-efficacy: $(n=130)$ & $n(\%)$ & \\
\hline Low (14-32) & - & \\
\hline Moderate (33-51) & $23(17.70)$ & \\
\hline High (52-70) & $107(82.30)$ & \\
\hline Total & $130(100.00)$ & \\
\hline BSES-SF & Mean (SD) & Median (Q1-Q3) \\
\hline Total Score & $60.57(5.07)$ & $62.00(58.00-64.75)$ \\
\hline
\end{tabular}

The score of the breastfeeding self-efficacy scale varies from 14 to 70 points. When the respondent obtains between 14 and 32 points, she is considered to have Low efficacy; between 33 and 51, Moderate; and between 52 and 70, High efficacy.

Most mothers (82.3\%) had scores compatible with high self-efficacy for breastfeeding (52-70 points) and there was no mother with low efficacy (Table 3).

Table 3. Comparison of the duration of breastfeeding with the mean scores of the breastfeeding self-efficacy scale

\begin{tabular}{|c|c|c|c|}
\hline \multirow{3}{*}{ Breastfeeding duration } & \multicolumn{2}{|c|}{ Breastfeeding Self-efficacy } & \multirow{3}{*}{$\mathrm{p}$-value } \\
\hline & Moderate & High & \\
\hline & Mean (SD) & Mean (SD) & \\
\hline Exclusive breastfeeding & $56.10(10.6)$ & $53.00(14.5)$ & 0.547 \\
\hline Non-exclusive breastfeeding & $60.00(0.0)$ & $58.70(5.3)$ & 0.487 \\
\hline
\end{tabular}

SD - Standard deviation

The relationship between self-efficacy and the duration of breastfeeding was assessed by measuring the correlation of the scale scores (BSES-SF) and the feeding time in days, as well as by comparing the time of breastfeeding among women with moderate and high self-efficacy.

There was no statistically significant difference in the comparison of mean time of exclusive and non-exclusive breastfeeding, within moderate and high efficacy scores.

\section{Discussion}

The limitations of the findings of this study are related to the fact that the sample was originated from only one service with specific characteristics, and the monitoring of EBF was performed only up to the 60th day after delivery.

In the sample studied, the findings did not enable to verify the self-efficacy scale as predictive for early weaning. On the other hand, its clinical applicability was verified as a reliable instrument to assess the perception of mothers about their breastfeeding self-efficacy, enabling professionals to identify mothers who are susceptible to succeed in breastfeeding, as well as those who may need intervention before hospital discharge.

The sociodemographic profile of the participants is consistent with the neighborhood where they reside, economically differentiated. The percentage of cesarean sections $(87 \%)$ is high, even for an institution that primarily assists patients using private health network, a result compatible with a 2010 study which identified a $63.6 \%$ rate of surgical births with an increasing trend, in these services. ${ }^{(10)}$

The need for implementation of strategies that enable women, assisted in the private network, to have access to guidance on breastfeeding is evidenced by the high percentage of pregnant women who received no information on the subject.

The mean duration of EBF was 53.2 days. This result is consistent with that identified in the last national survey of prevalence of breastfeeding in Brazilian state capitals and the Federal District, held in 2008, which identified a median EBF period of 54 days.

The expectation was to find longer periods of $\mathrm{EBF}$, since the mothers not only obtained moderate and high scores of breastfeeding self-efficacy, but also belong to a more privileged social class and presented high level of schooling, points considered important to maintain EBF.

The monitoring of EBF began on the 7 th day after delivery and $100 \%$ of women were exclusively breastfeeding their children. However, EBF showed a progressive decline, reaching $79 \%$, at 60 days. 
A study that monitored EBF up to 180 days after delivery revealed a higher number of abandonment after 60 days, and the percentage of mothers who exclusively breastfed up to the $60^{\text {th }}$ day $(70.4 \%)$ is slightly lower than that found in the present study (79\%). ${ }^{(11)}$

Rates of exclusive breastfeeding in Brazil are on a rise, but still below what is recommended by the WHO, which is 180 days. The percentage of $79 \%$ of children being exclusively breastfed, identified in this study, can be considered adequate, since the WHO attributes this concept when $50 \%$ to $89 \%$ of children under six months of age are exclusively breastfed. ${ }^{(11)}$ The application of the scale allowed to identify that mothers presented high and moderate efficacy and none of them obtained results consistent with low self-efficacy.

These results signaled that the mothers who participated in this study would probably maintain EBF for longer periods, a fact that was not consolidated at the end of monitoring.

A studythat used the same scale (Short Form) in 294 postpartum women also noted the absence of mothers with low efficacy. However, since the mothers were not followed up, it was not possible to compare the results. ${ }^{(7)}$

The comparison of the mean time of exclusive and non-exclusive breastfeeding, with the scores of moderate and high efficacy showed no statistically significant difference, which indicates that, in this study, the self-efficacy of the mothers did not influence the duration of breastfeeding.

Nevertheless, these results differ from those of the original study, conducted in Canada, which evaluated maternal confidence in breastfeeding among 130 Canadians and found that the higher the BSES score, the greater the likelihood of the women maintaining exclusive breastfeeding at 6 weeks postpartum $(\mathrm{p}<001)$. $^{(12)}$

Another longitudinal studycarried out in Australia with 300 pregnant women evaluated the influence of changeable factors in prenatal and breastfeeding duration. The scale was applied in the last trimester of pregnancy, at the 1st week postpartum and at baby's 4 months of life, and the results revealed that mothers who intended to breastfeed for less than 6 months were 2.4 times more likely to stop BF in 4 months than those who intended to breastfeed for more than 12 months. Similarly, the association of the BSES score with the duration of exclusive breastfeeding showed that mothers with higher self-efficacy scores were more likely to breastfeed longer, both one week and four months postpartum, than those presenting low self-efficacy in feeding $(\mathrm{p}<0.05) .{ }^{(13)}$

\section{Conclusion}

The results did not confirm whether the scale may be used as a predictor of risk of early weaning. In addition, no relation between greater scores of high efficacy and longer periods of exclusive breastfeeding was observed.

\section{Collaborations}

Souza EFC and Fernandes RAQ contributed to the project design, analysis and interpretation of data, drafting of the article, critical revision of the relevant intellectual content and final approval of the version to be published.

\section{References}

1. Brasil. Ministério da Saúde; Secretaria de Atenção à Saúde;Departamento de Atenção Básica. Saúde da criança: nutrição infantil: aleitamento materno e alimentação complementar [Internet]. Brasília; 2009 [citado 2011 maio 12]. Disponível em: http://portal. saude.gov.br/portal/saude/area.cfm?id_area=1461.

2. Brasil. Ministério da Saúde. II Pesquisa de Prevalência de Aleitamento Materno nas Capitais Brasileiras e Distrito Federal. Brasília: Editora do Ministério da Saúde; 2009; [citado 2010 Jun 20 ]. Disponível em: http://portal.saúde.gov.br/portal/arquivos/ pdf/pesquisa_pdf.pdf.

3. Queluz MC, Pereira MJ, Santos CB, Leite AM, Ricco RG. [Prevalence and determinants of exclusive breastfeeding in the city of Serrana, São Paulo, Brazil]. Rev Esc Enferm USP. 2012; 46(3):537-43. Portuguese.

4. Carvalho MR, Tavares LA. Políticas públicas em aleitamento materno. Amamentação bases científicas 3a ed. Rio de Janeiro: Guanabara Koogan; 2010. cap.17, p.277-9.

5. Passanha A, Benicio MH, Venancio SI, Reis MC. [Implementation of the Brazilian Breastfeeding Network and prevalence of exclusive breastfeeding]. Rev Saúde Pública. 2013; 47(6):1141-8. Portuguese.

6. Polido CG, Mello DF, Parada CM Carvalhaes MA, Tonete VL. [Maternal experiences associated with longer term exclusive breastfeeding: an ethnographic study]. Acta Paul Enferm. 2011;24(5):624-30. Portuguese. 
7. Dodt RCM. Aplicação e validação da breastfeeding self-efficacy scaleshort: em puerperas [dissertação]. Fortaleza: Universidade Federal do Ceará; 2008. Disponível em: http://www.revistarene.ufc.br/revista/ index.php/revista/article/view/579/pdf.

8. Dennis CL. The breastfeeding self-efficacy scale: psychometric assessment of the short form. J Obstet Gynecol Neonatal Nurs. 2003;32(6):734-44.

9. Salvetti MG, Pimenta CA. [Chronic Pain Self-Efficacy Scale portuguese validation]. Rev Psiq Clín. 2005; 32(4):202-10. Portuguese.

10. Brasil. Ministério da Saúde. Saúde Brasil 2011: uma análise da situação de saúde e de evidências selecionadas de impacto de ações de vigilância em saúde As cesarianas no Brasil: situação no ano de 2010, tendências e perspectivas. Disponível em: http:// portalsaude.saude.gov.br/portalsaude/arquivos/pdf/2013/Fev/21/ saudebrasil2011_parte2_cap16.pdf.

11. Rocci E, Fernandes RA. [Breastfeeding difficulties and influence in the early weaning]. Rev Bras Enferm. 2014; 67(1):22-7. Portuguese.

12. Dennis, C.L., Faux, S. Development and psychometric testing of the breastfeeding self-efficacy scale. Res. Nurs. Health.1999; 22(5): 399409.

13. Blyth RJ, Creedy DK, Dennis CL, Moyle W, Pratt J, De Vries SM, et al. Breastfeeding duration in an Australian population: the influence of modifiable antenatal factors J Human Lact. 2004;20(1): 30-8. 